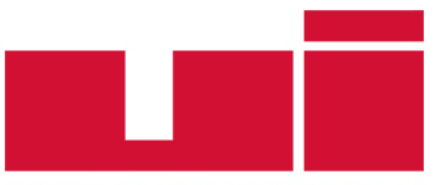

ULUSLARARASliLiŞKiLER
Akademik Dergi

Yayın ilkeleri, izinler ve abonelik hakkında ayrıntılı bilgi:

E-mail: bilgi@uidergisi.com

Web: www.uidergisi.com

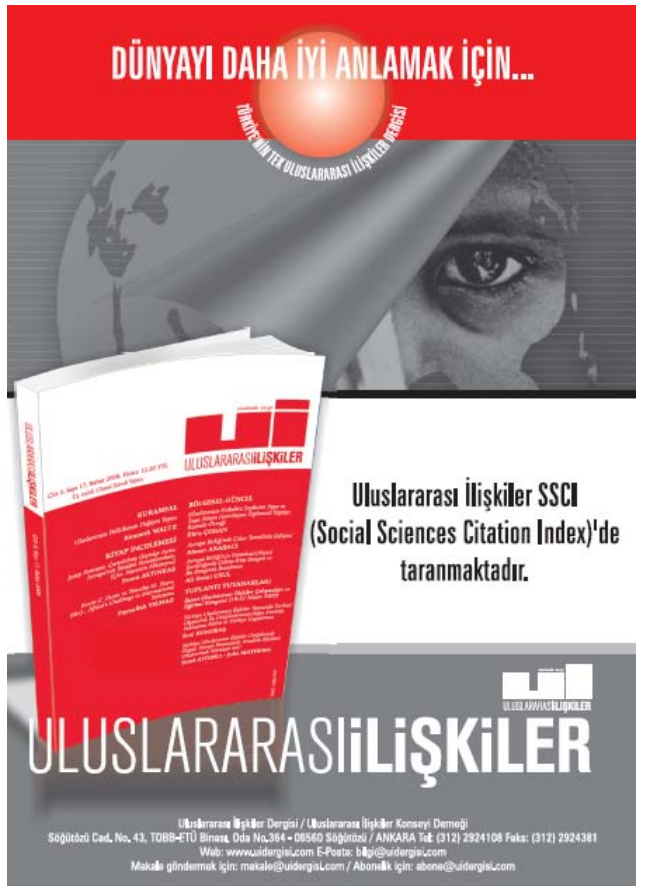

\title{
War and Peace in an Age of Terror and State Terrorism
}

\section{Richard Falk}

Milbank Professor of International Law and Practice, Princeton University

Bu makaleye atıf icin: Falk, Richard, "War and Peace in an Age of Terror and State Terrorism", Uluslararast Ilişskiler, Cilt 4, Sayı 14 (Yaz 2007), s. 1-15.

Bu makalenin tüm hakları Uluslararası İlişkiler Konseyi Derneği'ne aittir. Önceden yazılı izin alınmadan hiç bir iletişim, kopyalama ya da yayın sistemi kullanılarak yeniden yayımlanamaz, çoğaltılamaz, dağıtılamaz, satılamaz veya herhangi bir şekilde kamunun ücretli/ücretsiz kullanımına sunulamaz. Akademik ve haber amaçlı kısa alıntılar bu kuralın dışındadır.

Aksi belirtilmediği sürece Uluslararası Illişkiler'de yayınlanan yazılarda belirtilen fikirler yalnızca yazarına/yazarlarına aittir. UIKK Derneğini, editörleri ve diğer yazarları bağlamaz.

Uluslararası İlișkiler Konseyi Derneği | Uluslararası İlișkiler Dergisi Söğütözü Cad. No. 43, TOBB-ETÜ Binas1, Oda No. 364, 06560 Söğütözü | ANKARA Tel: (312) 2924108 | Faks: (312) 2924325 | Web: www.uidergisi.com | E- Posta: bilgi@uidergisi.com 


\title{
War and Peace in an Age of Terror and State Terrorism Richard FALK*
}

\begin{abstract}
ABSTIRACT
The 9/11 attacks on the United States unsettled our understanding of war and security in the world. This unsetting resulted partly because of the magnitude of the symbolic and substantive harm inflicted by a non-state actor lacking in military capabilities, and partly because the United States govern. ment responded by way of "war" rather than by reliance on "law enforcement." The discourse on war and peace is also confused by a reluctance to extend the label of "terrorism" to political violence by state actors against civilian innocence. The experience of the past five years calls for a rethinking of the relationship between "war," "law," and "security" in the global setting of the early 21 st century.
\end{abstract}

Keywords: Terrorism, State Terror, War, World Order, Political Violence.

\section{Terör ve Devlet Terörzmi Cağnda Savas ve Barus}

\section{OZZET}

Amer ka Birleşik Devletleri'ne karşı gerçekleştirilen 11 Eylül saldurılan, savaş ve güvenlik üzerine yerleşik anlayışı derinden etkiledi. Bu etki, kısmen, askeri yeteriklerden yoksun bir devlet-dişı aktörün neden olduğu sembolik ve maddi zararin büyüklüğü; kısmen de, Amerikan yönetiminin "hukuku işletme" yerine "savaş"la karşılık verme yönünde iradesi ile ortaya çıtı. Savaş ve barış söyleminin hedef olduğu bir başka karmaşa, devlet aktörleri tarafindan masum sivillere uygulanan siyasal şiddeti "terorizm" kapsamma alma konusunda gösterilen isteksizliktir. Son beş yılda tecrübe edilen gelişmeler, 21. yüzyılın başlangıcını oluşturan yeni küresel bağlamda, "savaş," "hukuk" ve "güvenlik" arasındaki ilişkilerin yeniden düşünülmesini gerektirmektedir.

Anahtar Kelimeler: Terörizm, Devlet Terörü, Savaş, Dünya Düzeni, Siyasal Siddet.

* Albert G. Milbank Professor of International Law and Practice, Emeritus, at Princeton University; Visiting Professor, Global Studies, University of California, Santa Barbara, falk@global.uesb.edu 
There are strong reasons to resist an interpretation of the current world situation that raises above all other concerns the violent interaction of states and non-states. And there are additional reasons to be reluctant to be content with labeling such interaction by the inflammatory terminology of "terror," "terrorist," and "terrorism." Since governments and the media are likely to continue to use this way of talking about their adversaries, it is at least important to associate terrorism with political violence that targets civilians, independent of whether the actor is a non-state movement or a sovereign state. Such usage at least challenges the propagandistic allegations directed at any enemy of the state.

After the ending of the Cold War, and the collapse of the Soviet Union, there occurred a decade of relative calm with respect to war and peace in the world. There were many bloody conflicts taking place, especially in formerly colonized countries, but little threat or concern about the outbreak of major wars between states, except possibly with respect to India and Pakistan. The new emphasis was on warfare within sovereign states, and the extent to which the UN and outside actors had a duty to intervene under certain conditions. ${ }^{1}$ This focus was superseded after the $9 / 11$ attacks by a preoccupation with transnational organized political violence in which the principal actors were not normal states, as was the case for wars in the modern period. But now the "war" was being carried on between a transnational network of dedicated extremists (Al gaeda) and a global state that pursued its interests on a planetary scale. Despite the cautionary comments, it seems useful to explore the significance of this struggle between post-Westphalian actors in relation to the future of world order and with regard to global and human security.

\section{The Globalization of Political Violence}

Let me begin this examination of the changing world order scene by acknowledging with some shame that my own early response to the September 11 attacks was to speak out in favor of the "war" against Afghanistan, and more generally to endorse the war discourse adopted by the Bush presidency. ${ }^{2}$ At the time, it seemed that no government could or should ignore the threat posed by Al Gaeda,

1 For an illuminating assessment of this shift of emphasis from inter-state warfare see Mary Kaldor, New and Old Wars: Organized Violence in a Giobal Era, Stanford, CA, Stanford University Press, 1999.

2 These views were initially expressed in several articles appearing in The Nation in the weeks following September 11, 2003, and then more fully elaborated in my book The Great Terror War, Northampton, MA, Olive Branch Press, 2003. 
its ideology of indiscriminate violence and jihadist politics, as well as its demonstration of a capacity and will to mount an attack that inflicted severe symbolic and substantive harm on what had seemed as late as September 10 to be the most secure and powerful state on the planet. No sovereign state would have dared launch such an attack against the United States, assuming that the response would be so devastating as to effectively end its existence as a political entity. In this sense, and perhaps in this sense alone, September 11 did signal the superseding of Westphalian warfare by something entirely different, and as yet still unnamable, and seemingly unmanageable, undermining the security of even the strongest states.

In 2001, I supported a public position that initiating a war against Afghanistan was a "just war" that could be validated by a lexible reading of international law. It was notable that the prospect of such a war disturbed neither the United Nations nor aroused an adverse public opinion. It appeared reasonable, and even necessary, to disrupt the leadership and destroy the headquarters of Al Qaeda in retaliation for its role, and with greater reason, to reduce the danger and size of future attacks. It also seemed reasonable to hold the Taliban regime at least indirectly responsible for the September 11 attacks, and to make regime change in Kabul a legitimate war goal for the United States. There were additional grounds to disregard the sovereign rights of Afghanistan: the oppressiveness of its Taliban government that was itself guilty of many crimes against humanity and the legally dubious political status of the regime in the world, the government then having diplomatic relation with only a single state, its neighbor, Pakistan, and then only for practical reasons of maintaining a communications link with the outside world.

More than five years later I can hardly comprehend my earlier understanding of the issues, and stress this change of heart because I think it helps us realize why a renewed inquiry into "terrorism" is both necessary partly because first reactions turned out to be so inadequate. Of course, even at the end of 2001, I began to have serious misgivings about how the Afghanistan War was waged, the disregard of civilian life, the over-reliance on air power, the vindictive mistreatment of captured personnel, and the general ineffectiveness of the military operations with respect to apprehending the Al Gaeda leadership and shattering its capabilities for further attack. It then also became clear that it was likely a huge mistake to regard counter-terrorism as a species of "war" rather than as a particularly difficult "law and order" 
challenge. This mistake was, perhaps, natural in the immediate aftermath of $9 / 11$ due to the magnitude of the attacks that created an impact that for Americans was more like Pearl Harbor than any of the earlier terrorist incidents and given the Al Qaeda declaration of war against the United States. Nevertheless, especially given neoconservative influence on American foreign policy, the decision to go to war rather than to enforce law in the face of high profile criminality has had a huge adverse impact.

What most unsettled my initial views about responding to $9 / 11$ was that it became increasingly clear that "the terrorist card," despite the official rhetoric of a "global war on terror" was not even principally about "terrorism," or even about the rise of dangerous, extremist non-state actors targeting the United States and its citizens for violent annihilation. The counter-terrorist campaign was actually functioning as a gigantic public relations campaign mounted by the Bush presidency and designed to divert at tention from the real undertaking: the full-scale pursuit of a grand strategy by the United States to achieve and sustain global dominance by military means, with an initial preoccupation about achieving hegemonic control over the Middle East, perhaps better designated in Japan as West Asia. To carry out such an ambitious and controversial foreign policy it was necessary to mobilize the American people to offer their children as potential war victims and to pay the high costs of embracing a risky imperial geopolitics. Neoconservative think tanks and leading reactionary voices in Washington had advocated this grand strategy of global domination ever since the end of the Cold War. But until the 9/11 attacks there was no rationale for such a foreign policy that would have been politically acceptable within the American setting, which at least ideologically was anti-imperialist and pacific. When George W. Bush initiated the "Great War on Terror" it was from the outset a mind game that was played with the sensible political reluctance of a democratic society to embark on a course of aggressive war making, yet always more than ready to support wars of selfdefense with patriotic fury. In this sense, the war against Afghanistan seemed at the time to be an appropriate defensive response to the shock and fear and anger in America that accompanied the $\mathrm{Al}$ Qaeda attacks, and not the launch of a far broader and more dubious global strategy. In reality the Afghan War mainly functioned as a hyped prelude to the wider neoconservative campaign to shift the center of gravity of American foreign policy from Europe to the Middle East. Such an assessment seems highly persuasive in light of the American failure to complete the job of stabilizing Afghanistan after the Taliban regime was toppled and the country occupied. There was an unseemly haste exhibited by the U.S. Government in 
shifting immediately its main "counter-terrorist" energies to Iraq. The absence of any terrorist threat from that country and its weakness as a result of the Gulf War of 1991 and twelve subsequent years of punishing sanctions aroused widespread suspicions about the real goals of American foreign policy. ${ }^{3}$

For neoconservatives $9 / 11$ was the opportunity they had been waiting for. It was all the encouragement that was needed to lead the Bush leadership to take geopolitical advantage of the hitherto neglected opportunities provided by unipolarity. The collapse of the Soviet Union produced the historically unusual circumstance of a geopolitical vacuum, that is, the absence of any significant Westphalian countervailing forces confronting American global ambitions; to the extent that Al Qaeda and its surrogates opposed these ambitions it was from a post-Westphalian perspective signaling the rise of non-state actors. This broader agenda of American global policy represented a comprehensive interpretation of challenges and opportunities that involved several main areas of concern. In addition to taking favorable account of the geopolitical setting and responding to the challenge of extremist non-state actors, neoconservatives were concerned about the securing under American control the vast oil reserves of the Middle East, a rising priority given the growing energy squeeze. This neoconservative outlook was also particularly responsive to right-wing Israeli insecurities and ambitions, as well as exhibiting anxiety about a challenge to U.S. dominance that could be mounted by China in the near future. Additionally, neoconservatives feared that some patterns of the proliferation of nuclear weapons could curb American freedom of maneuver, especially in the Third World, associated with unipolarity.

This governmental mind game played for American support took various forms. Its initial emphasis was an insistence on expectations of unity (that is, the absence of criticism by citizens) given the existence of wartime conditions. Because this struggle did not seem like a normal war, the government needed to rely on the manipulation of fears, periodically making the terrorist threat seem far more menacing and immediate than it turned out to be. In the years after $9 / 11$ the Bush presidency also made opportunistic use of a reawakened American patriotism that seemed ready and willing to suspend the most fundamental rights associated with a democratic society, turning a blind eye toward governmental abuse, especially when directed at Muslims. Most abusive were the policies directed at supposed terrorist suspects whose most fundamental rights were suspended. Anxieties rose that the

3 See sanctions chapter, Richard Falk, The Costs of War, New York, Routledge, 2007. 
United States was moving in authoritarian direction, its officials openly defending practices generally viewed as violating the international norm prohibiting torture. This disturbing encroachments on constitutional democracy in the name of counter-terrorism became the essence of homeland security in the United States. But in this regard it is helpful to have some historical perspective. Matthew Carr expertly demonstrates in his fine book, The Infernal Machine: A History of Terrorism, that such patterns of abusive, superfluous, and cruel counter-terrorism has been a consistent theme ever since the end of the nineteenth century when modern. governments began to be faced with radical challenges mounted by extremist political groups who resorted to political violence to gain their ends.4 Particularly characteristic of past governmental responses has been a reliance on torture and a willingness to fabricate terrorist incidents so as to build a public relations case for claiming enhanced powers due to the existence of a national security emergency. What seems distinctive about the post-9/11 approach of the U.S. Government is its fusing of a turn toward domestic oppression with its moves toward foreign wars and imperial geopolitics.

Against such a background it is hardly surprising that there has surfaced a tsunami of suspicion with respect to the seminal events of September 11. A growing grassroots movement ha. emerged that questions whether the official story that has bee: told about how and why September 11 happened is believable. Among those who have dared to consider gaps in the evidence carefully there are strong reasons to suspect that high officials in the US Government at least deliberately refused to take precautionary steps in response to several highly reliable and rather specific warnings of an impending attack, and there lurks the possibility that some officials may have been complicit to a greater degree. David Griffin's several books arguing this case cannot be easily disregarded as the ravings of a conspiracy theorist, although they have been to this point ignored in the mainstream media; ${ }^{5}$ Griffin is a philosopher of religion of worldwide reputation and impeccable scholarly credential, known especially for his work on the great British philosopher, Alfred North Whitehead. Griffin has devoted

4 Matthew Carr, The Infernal Machine: A History of Terrorism, New York, The New Press, 2006.

5 David Ray Griffin, The New Pearl Harbor: The Disturbing Questions about the Bush Administration and 9/11. Northampton, MA, Olive Branch Press, 2004; 9/11 Commission Report: Omissions and Distortions, Northampton, MA, Olive Branch Press, 2005; Debunking 9/11 Debunking: An Answer to Popular Mechanics and Other Defenders of the Official Conspiracy Theory, Northampton, MA, Oliver Branch Press, 2007. 
himself in recent years to a well-reasoned and abundantly documented exposure of the extraordinary tensions between the official version of what happened and the available evidence as what seems to have actually happened. Whatever the eventual historical unraveling of September 11, the response certainly demonstrates that the vulnerability of a democratic society may be greater from its own manipulative forces than it is from those who are feared as "evil" and as "enemies." These anti-democratic domestic forces are often concealed in the deep recesses of governmental bureaucracy, and are ready to make common cause with their right-wing allies when opportunities exist, especially at times of national crisis.

These various concerns eroded my willingness to give the Bush presidency any further benefit of the doubt with respect to its war on terrorism, but what turned out to be decisive in changing my thinking was the buildup toward the war against Iraq. Here, to me it was obvious that a war was being planned that could not be reconciled with international law and that intended to flaunt the authority of the United Nations. What is more it was a war that threatened great devastation and was fraught with dangerous unpredictability. The more sophisticated among the advocates of the Iraq War should have realized that its only convincing justification related to the geopolitical gains that would result from military victory (oil, Israeli security, strategic position, the demonstration effects of military victory) more than offsetting the unacknowledgeable costs likely to result from the anticipated intensification of anti-American terrorism. The Egyptian leader, Hosni Mubarak, emphasized the point when he said before the invasion of Iraq that such a war would give rise to fifty new Osama Bin Ladens. To summarize the argument: the so-called war on terror was never primarily about terrorism, except that the counter-terrorist narrative emboldened the government to abuse its opponents, including even its own citizens. It is a misleading concession to the geopolitical manipulators of $9 / 11$ to consider this to be "an age of terrorism." A more illuminating orientation for the political imagination is "the age of global empire" or a period that can be most saliently associated with the global state, globalization, religious resurgence, beyond Westphalia, human rights, climate change. There are many plausible candidates for a defining characteristic of our time, but terrorism is not one of them, particularly if an observer is not entirely shaped by American perceptions of world order. It is not merely a matter of unwarranted deference to an American-centric view to treat 9/11 as the decisive rupture of our time that changed everything, it is also to fall prey 
to geopolitical propaganda designed to divert attention from the pursuit of a global dominance project, which cannot be directly admitted.

Even if we temporarily suspend disbelief with respect to our doubts about September 11, and accept the view that the attacks should be perceived more or less as presented to the public, then what' As suggested, no government could ignore the challenge, but did it need to declare "war," and especially a war without a specific opponent, one to be waged worldwide against a form of behavior, that is, against "terror"? Why lump together the Al Qaeda vision of a transformed Islamic world with the various struggles of selfdetermination being waged in such diverse settings as Palestine, Kashmir, Chechnya? In domestic settings, it would be a regressive misreading of political reality to treat all violent political adversaries as "terrorists" who deserve to be exterminated or controlled. There is a notable difference between the IRA, ETA, and the FLN in Algeria and such visionary and sociopathic terrorists that challenge the nature of the social order itself as was the case with Aum Shinrikyo, the Red Army Faction (Germany), and the Red Brigades (Italy). Such an over-generalizing response by the U.S. Government served well the geopolitical ambitions of the neoconservative presidency that orchestrated the response to September 11 , but it was dysfunctional from the perspective of the genuine containment of the actual threat posed by Al Qaeda and its allies.

It is instructive to compare the Spanish response to the Madrid train bombings of March 1 1, 2004, or even the British response to the London attacks of July 7, 2005. In both instances, the response was based on drawing a sharp distinction between "war" and "terrorism." Terrorism, if the terminology can ever be constructively used at all given its many manipulative applications, should be always treated as justifying a law enforcement challenge, at worst, giving rise to a type of Crime Against Humanity that validates a major societal effort. In contrast, the idea of war refers us to armed struggles by contending forces over territorial boundaries or political control, whether within or between states. Most serious and sustained instances of modern terrorism can be best comprehended as resistance to foreign occupation. This position has been empirically argued by Robert Pape in his recent book on suicide bombing, Dying to Win: The Strategic Logic of Suicide Ter rorism. ${ }^{6}$. In Spain the response to the train bombings was organized by reference to the main slogan used at mass public

6 Robert Pape, Dying to Win: The Strategic Logic of Suicide Terrorism, New York, Random House, 2006. 
demonstrantions: "No to War, No to Terrorism." It led in Spain to the electoral repudiation of one of the few political leaderships in Europe that had sided with the United States in the Iraq War, and to the subsequent withdrawal of Spanish participation in the war. But it also produced a more vigilant police effort to protect Spanish society against subsequent attacks, which included the arrest of the perpetrators and their accomplices. A similar approach was followed in Britain, somewhat marred by some indications of police over-reactions, but generally keeping the cause of counter-terrorism apart from the ill-considered willingness of the Blair government to become a junior partner of the United States in embarking upon the Iraq War. What seems clear, then, is that if counter-terrorism is the real goal, then two moves are vital: an acknowledgement of and attention to legitimate grievances that gave rise to extremist behavior and an enhanced effort to improve police capabilities to prevent terrorism and to foster police cooperation within and among states. In fact, Al Qaeda has been strengthened by the wars waged against it, while seriously weakened by the law enforcement breakthroughs that have dealt with extremist cells in various parts of the world and have apparently curtailed the capacity of such groups to achieve tactical successes via violent acts. Increased societal vigilance seems to have made it more difficult to mount terrorist attacks.

\section{The Relevance of State Terror}

Turning from terrorism, anti-state political violence, to "state terrorism" gives us another disturbing understanding of the deployment of violence by state actors against essentially innocent civilians, that is, civilians in the same sense that the hapless occupants of the Trade Center buildings on September 11 were innocent. The main dynamic of modern warfare consists of the constant, often frantic, effort to render technology and strategic doctrine ever more potent in their terroristic potential with respect to civilian populations. This became morbidly prominent in World War II when the Allied Powers fighting a just war relied on a self-proclaimed doctrine of "total war" that featured repeated strategic bombing attacks on large cities designed to inflict maximum casualties on German and Japanese societies with the declared intent of so demoralizing the population as to encourage its rejection of the war effort. These tactics culminated in the atomic bombings at the end of the war justified by apologists then and since as "saving American lives" by inducing a rapid Japanese surrender.

During the Cold War this genocidal mentality that had come to shape the conduct of major Westphalian wars between leading states 
reached survival-threatening heights through the deployment of hundreds of nuclear weapons accompanied by doctrines of deterrent, a security regime labeled "mutual assured destruction," with the revealing acronym of MAD, and also known more descriptively as "the balance of terror." Against this declared willingness of leading states to rely on city-busting nuclear weapons, the attacks on the World Trade Center and Pentagon, however horrifying, are trivial by comparison. As E.P. Thompson influentially explained, any culture that reveals a willingness to rely on genocidal policies for its security thereby undermines its own moral credibility even if the threat is never carried out. Such a state certainly has forfeited its anti-terrorist credentials, or any claim to serve as the arbiter of "civilization," itself is a contested reality in view of the historical Euro-centric story of acting as the vehicle of civilization. For the colonialist antecedents of state terrorism see the searing account of European policies in Africa that are so vividly recounted by Sven Lindquist in "Exterminate All the Brutes:" One Man's Odyssey Into the Heart of Darkness and the Origins of European Cenocide.

It is ominously instructive that the widespread reliance by military personnel and intelligence officers on coercive interrogation techniques, that is, torture, since September 11, has similarly been publicly justified by President Bush in his notorious speech of September 6, 2006, or more recently by the former director of the CIA, George Tenet, in his defense of the agency, as necessary "to save American lives." This deep and presumably unconscious, and certainly unacknowledged, moral depravity and lawlessness associated with the deliberative mass sacrifice of innocent lives for the sake of political ends has been characteristic of Western war-fighting for centuries, and continues to taint all gestures to bring collective violence within the discipline of law.

Returning to the post-September 11 framing of terrorism and state terror, it is worth observing that President Bush often accused the terrorists of waging a war against civilization, and as thereby being the embodiment of evil. But what is it that is being labeled "civilization" except a governmental actor that has a shameful record of engaging in state terrorism on a scale that dwarfs any undertaking by "the terrorists," that is, the political violence of non-state actors. There are many manifestations of state terrorism in this current period, but perhaps the most emblematic was the "shock and awe" tactics used to initiate the 
unprovoked aggressive war against Iraq in 2003, lighting up the slry over Baghdad with a massive and undoubtedly terrifying display of high technology military ordinance. Over and over again in the Iraq War, the United States has relied upon overwhelming displays of high technology firepower to make Iraq cities such as Falluja uninhabitable, inflicting massive casualties on a helpless civilian population that had been promised liberation not subjugation and horror prompting many Iraqis with the means to flee the country forever.

Having established the rather level moral playing feld as between non-state and state terror, a less violent future can be imagined even if cannot now be anticipated. It is encouraging that neither form of terroristic violence can any longer attain their political goals at all, or at acceptable costs. Purely visionary projects, whether overturning a major established society or ruling the world, require a purely enforcement oriented response as was developed to cope with urban terrorism of the $1970 \mathrm{~s}$ and $1980 \mathrm{~s}$. In contrast, violent movements that seek to address legitimate grievances, struggles for self-determination or against oppressive rule, normally depend for settlement upon mediation and nonviolent forms of conflict resolution, converting the terrorists of yesterday into the political leaders of today. Consider, for instance, the dramatic upgrading of such diverse figures as Nelson Mandela, Yasir Arafat, and Gerry Adams. It only delays political accommodations, often at great human and societal costs on both sides, to deny the existence of legitimate grievances. How many Palestinians and Israelis will have to die and suffer before political leaders reach an accord that affirms and implements the Palestinian right of self-deternination more or less in accordance with the green line that existed before the 1967 War? How many Catholics and Protestants endured bloodshed and acute insecurity before the conflict was shifted from para-military theaters of combat to political arenas of negotiation and accommodation?

We cannot know whether the Al Gaeda challenge is purely visionary, in the mode of Aum Shinrikyo, or at least partly instrumental, seeking the removal of certain legitimate grievances. But we know that fighting terror with state terror feeds the fires of violence and extreme resentment with escalating effects on the overall scale of death and destruction. We also know that there are well-founded legitimate grievances in the Islamic world directed against the West, but especially the United States. It seems clear that reinforcing Israeli oppressive and exploitative policies toward the Palestinians and Arab neighboring states has generatid a deep sense of humiliation and anger among the Arab masses in these societies. It also is evident that years of sanctions imposed on the Iraqi population after the First Gulf War, between 1991 and 
2003. caused hundreds of thousands of Iraqi deaths. This experience reinforced the general perception of the West, and especially of the United Nations, as a cruel oppressor of Arab peoples. Furthermore, the huge American military presence in the region undoubtedly acts as a reminder of the colonial past, and its substantial removal could alone signal a respect for the independence of the countries in West Asia.

\section{Conclusions}

In concluding, I would say that war has been widely discredited as a counter-terrorist response, both on grounds of propriety and effectiveness, but that elites and their publics have not begun to perceive this fundamental shift in political realities. It is also abundantly clear that from the perspective of civilian values, that the state terrorism associated with counter-terrorism and one-sided warfare, is by far the greatest cause of harm throughout human history. Finally, a state that seeks to defend itself, should regard the rule of law as its first and main line of defense, and limit its reach overseas by reliance on cooperative police enforcement procedures, complemented by the new options offered by international criminal law, especially the International Criminal Court. Beyond this, self-scrutiny to the extent of resolving legitimate grievance in an equitable manner might be the optimal response to most forms of non-state political violence, at least providing an approach of first resort.

I would also make a second observation that relates to the blurring of the boundaries between peace and war, a process that had characterized the hair alert realities of the Cold War epoch, but now is associated with the interplay of terror and counter-terror. Intrusive violence or unanticipated detention can occur anywhere, at anytime, without prior warning. Such violence against the person can be generated either by the state in its suppressive mode, holding anyone under suspicion in detention indefinitely, or it can result from non-state actors dedicated to the omega point of suicide to kill as many people as possible and to frighten everyone in a targeted society. There is a heightened awareness of risk everywhere, often opportunistically intensified by government propaganda, making it impossible to evaluate the degree of risk with any confidence. ${ }^{8}$ This post-September 11 atmosphere is well-de-

8 See, generally, the pre-9/11 emphasis on the centrality of risk in modern society in the work of Ulrich Beck, Risk Society: Toward a New Modernity, Newbury Park, CA, Sage, 1992; and World Risk Society, Cambridge, Polity, 1999; also Ulrich Beck, Anthony Giddens and Scott Lash, Reflexive Modernization: Politics, Tradition and Aesthetics in the Modern Social Order, Stanford, CA, Stanford University Press, 1994; also relevant is David Runciman, The Politics of Good Intentions: History, Fear, and Hypocrisy in the New World Order, Princeton, NJ, Princeton University Press, 2006. 
picted in the insightful novel of lan McEwan entitled Saturday. Toward its end, writing in the setting of London on February 15, 2003, the day of the great anti-war demonstration that preceded the Iraq War, the main character ponders this pervasive mixture of certainty and uncertainty that makes the moment so perplexing:

Beware the utopianists, zealous men certain of the path to the ideal social order. Here they are again, totalitarian in different form, still scattered and weak, but growing, and angry, and thirsty for another mass killing. A hundred years to resolve. But this may be an indulgence, an idle, overblown fantasy, a nightthought about a passing disturbance that time and good sense will settle and rearrange. ${ }^{9}$

Of course, such reflections themselves exhibit the anxieties of the privileged accustomed to the security that well-governed states have provided between its wars, but there are existentially traumatizing anxieties of those caught between these two sets of antagonistic forces, swept up frighteningly by arbitrary government dragnets or annihilated by the desperate tactics of the darkly alienated. We have no way of knowing whether it will be possible, or even desirable, to restore Westphalian normalcy to modern societies or to establish new forms of post-Westphalian, postmodern security that recreate the possibility of reasonable levels of societal security. Unfortunately at this moment it requires a utopian sensibility to anticipate a hopeful future, but still our sense of human dignity depends on thinking and acting as if such a future is possible.

This discussion of terror and state terror should not exhaust our concerns about war and peace in the early $21^{\text {st }}$ century. Despite the rise of non-state actors, both from below in the form of insurrectionary challenges and from above in the form of imperial geopolitics, there are other serious issues that deserve our attention. These include the existence of a nuclear weapons arsenal of some 27,000 nuclear warheads, 3,500 of which are on hair trigger alert. Any accident or pathological initiative could instantly overshadow the sorts of concerns that have dominated the political imagination in the West since 9/11. And then, it is more than a fanciful possibility, that miscalculations or extremism could lead to devastating wars as between Pakistan and India, North Korea and South Korea and Japan, China and the United States. That is, although Westphalian war, that is, between territorial states, seems to be receding, serious dangers and uncertainties remain, and most state actors are arming themselves, some at great expense. The United States is wasting its wealth by over-investing in this

9 Ian McEwan, Saturday, New York, Random House, 2005, p. 286. 
obsolescent Westphalian war machine, and depriving itself and the world of a much more prudent distribution of expenditures, including on improving the environment, reducing world poverty and disease, and renewing its own societal infrastructure. In the end, our future prospects depend on appreciating the character of new security challenges while remaining prudently attentive to the sorts of unresolved tensions that often led to wars in the past. 


\section{Bibliography}

Beck, Ulich, Risk Society: Toward a New Modernity, Newbury Park, CA, Sage, 1992.

World Risk Society, Cambridge, Polity, 1999.

Beck, Ulrich, Anthony Giddens and Scott Lash, Reflexive Modernization: Politics, Tradition and Aesthetics in the Modern Social Order, Stanford, CA, Stanford University Press, 1994.

Carr, Matthew, The Infernal Machine: A History of Terrorism, New York, The New Press, 2006.

Falk, Richard, The Great Terror War, Northampton, MA, Olive Branch Press, 2003.

The Costs of War, New York, Routledge, 2007.

Griffin, David Ray, The New Pearl Harbor: The Disturbing Questions about the Bush Administration and 9/11. Northampton, MA, Olive Branch Press, 2004.

9/11 Commission Report: Omissions and Distortions, Northampton, MA, Olive Branch Press, 2005.

Debunking 9/11 Debunking: An Answer to Popular Mechanics and Other Defenders of the Official Conspiracy Theory, Northampton, MA, Oliver Branch Press, 2007.

Kaldor, Mary, New and Old Wars: Organized Violence in a Global Era, Stanford, CA, Stanford University Press, 1999.

Lindquist, Sven, "Exterminate All the Brutes:" One Man's Odyssey Into the Heart of Darkness and the Origins of European Genocide, New York, The New Press, 2007.

McEwan, Ian, Saturday, New York, Random House, 2005.

Pape, Robert, Dying to Win: The Strategic Logic of Suicide Terrorism, New York, Random House, 2006.

Runciman, David, The Politics of Good Intentions: History, Fear, and Hypocrisy in the New World Order, Princeton, NJ, Princeton University Press, 2006. 